Biol. Stud. 2015: 9(3-4); 31-40 • DOI: https://doi.org/10.30970/sbi.0903.445

www.http://publications.Inu.edu.ua/journals/index.php/biology

\title{
5
}

UDC 576.314:612.35:577.152.39

\section{INFLUENCE OF NAADP AND BAFILOMYCINE A1 ON ACTIVITY OF ATPase IN LIVER POSTMITOCHONDRIAL FRACTION}

S. Bychkova

Ivan Franko National University of Lviv, 4, Hrushevskyi St., Lviv 79005, Ukraine e-mail: s.bychkova@gmail.com

Recycling of the endo-lysosomal organelles occur by permanent in the cell. This store is thought to be the acidic store because V-type of $\mathrm{H}^{+}$-ATPase is responsible for their acidification. Bafilomycine A1 is a selective inhibitor of vacuolar $\mathrm{H}^{+}$ATPase, and is often used as anticancer drug. However, it is not clear if applying of bafilomycine A1 is safe for normal cells. Endo-lysosomes are important cellular $\mathrm{Ca}^{2+}$ storage, sensitive to nicotinic acid adenine dinucleotide phosphate (NAADP). Hepatocytes were shown to have NAADP-sensitive acidic store. But the correlation between acidic store and endoplasmatic reticulum or plasmatic membrane during endo-lysosomal organelles recycling and fusion is still unknown. The main goal of this study was to examine influence of bafilomycine $\mathrm{A} 1$ and NAADP on activity of $\mathrm{Na}^{+} / \mathrm{K}^{+}$-ATPase, basal $\mathrm{Mg}^{2+}$-ATPase and $\mathrm{Ca}^{2+}$-ATPase of plasmatic membrane (PM) and endoplasmatic reticulum (ER) for better understanding of the relationship between acidic organelles and PM/ER. Besides possibility of bafilomycine A1 applying as anticancer drug is examined. All experiments were conducted using rat liver postmitochondrial fraction.

It was shown that SERCA activity is increasing under bafilomycine A1 presence, as well as NAADP. At the same time, changes in PMCA activity was not found. Preincubation of rat liver postmitochondrial fraction with bafilomycine A1 completely prevented NAADPinduced increasing of SERCA activity. Bafilomycine A1 decreased activity of $\mathrm{Na}^{+} / \mathrm{K}^{+}-$ ATPase and amplificated NAADP-induced decreasing of this pump. Applying of NAADP caused more intensive decrease in $\mathrm{Na}^{+} / \mathrm{K}^{+}$-ATPase activity after preincubation of this fraction with bafilomycine A1. It was also shown that bafilomycine A1 caused increasing of basal $\mathrm{Mg}^{2+}$-ATPase activity and NAADP intensify bafilomycine A1-induced changes of function of this pump. These effects are realized due to changes of $\mathrm{pH}$ inside the endolysosomal ogranels, acidification of incubation medium, as well as calcium concentration in local contact sites.

A conclusion was made that NAADP-sensitive store is bafilomycine A1-sensitive, which also has direct contact sites to ER, but not to PM. Besides, existing of NAADPsensitive, but bafilomycine-insensitive store in this fraction is supposed, which is more likely represented by endosomes. So, applying bafilomycine A1 in anticancer therapy may cause a damage of endo-lysosomal organelles recycling in healthy cells.

Keywords: NAADP, bafilomycine $\mathrm{A} 1, \mathrm{H}^{+}$-pump, $\mathrm{Na}^{+} / \mathrm{K}^{+}-\mathrm{ATP}$ ase, SERCA, PMCA, basal $\mathrm{Mg}^{2+}$-ATPase, endosomes, lysosomes.

ISSN 1996-4536 (print) • ISSN 2311-0783 (on-line) • Біологічні Студії / Studia Biologica • 2015 • Том 9/№3-4 • С. 31-40 


\section{INTRODUCTION}

Eukaryotic cells contain lysosomes, with the exception of some highly specialized cells such as mammalian erythrocytes. Lysosomes degrade exogenous and endogenous macromolecules derived from biosynthetic and endocytic pathways, and catabolize cytosolic components that are obtained from the autophagic pathway [22]. Lysosomes, lysosome-related organelles, and endosomes are important $\mathrm{Ca}^{2+}$ storage cellular compartments with a crucial role in intracellular $\mathrm{Ca}^{2+}$ signalling. V-type $\mathrm{H}^{+}$-ATPases are responsible for acidification of these organelles. Bafilomycin A1, a macrolide antibiotic isolated from the Streptomyces species, is an inhibitor of vacuolar $\mathrm{H}^{+}$-ATPase (V-ATPase). It binds to the $\mathrm{V}_{0}$ sector subunit $\mathrm{C}$ of the $\mathrm{V}$-ATPase complex and inhibits $\mathrm{H}^{+}$translocation, causing an accumulation of $\mathrm{H}^{+}$in the cytoplasm of treated cells [2]. The anticancer effects of bafilomycin A1 are considered to be attributable to the intracellular acidosis caused by V-ATPase inhibition. However, it is not clear it applying of bafilomycine A1 as anticancer drug is safe for normal cells.

Bafilomycin A1 has been used in the study of autophagy as an inhibitor of fusion between autophagosomes and lysosomes and as an inhibitor of lysosomal degradation [26]. Autophagy is a cellular catabolic pathway that is involved in lysosomal degradation and recycling of proteins and organelles, and therefore is considered as an important survival mechanism for both normal cells and cancer cells in response to metabolic stress or chemotherapy. The defects in these processes can result in disease.

Interest to endo-lysosomes as $\mathrm{Ca}^{2+}$-storage organelles has intensified with the discovery that NAADP (nicotinic acid adenine dinucleotide phosphate), a $\mathrm{Ca}^{2+}$-mobilizing messenger first discovered to evoke $\mathrm{Ca}^{2+}$ signals in sea urchin eggs [9], does so in many cases by activating $\mathrm{Ca}^{2+}$-release mechanisms on acidic stores with characteristics of lysosomes [4]. The fundamental question that remains unanswered is the identity of the NAADP receptor. Transient receptor potential mucolipin (TRPML) and twopore channels (TPCs) are $\mathrm{Ca}^{2+}$-permeable ion channels revealed within the endolysosomal system. Both structures have been proposed as potential targets for NAADP [19]. Besides, it was shown that TPCs are not gated by NAADP [8]. It was identified an endolysosomal ATP-sensitive $\mathrm{Na}^{+}$channel (lysoNa $\mathrm{NTP}_{\text {AT }}$ ), which is a complex formed by TPCs 1 and TPCs2 and mTOR (mammalian target of rapamycin) [8]. Although there is substantial evidence that RyRs are the principal effectors of cADPR-induced $\mathrm{Ca}^{2+}$ release from the endoplasmic reticulum (ER), a number of studies have also implicated RyRs in NAADP-evoked $\mathrm{Ca}^{2+}$ release [10; 12].

It was suggesed that the effect of NAADP is dependent on ER luminal calcium in hepatocytes [6]. Besides, it was also assumed that RyRs have been involved in indirect modulation of the NAADP effect via increasing the level of ER luminal calcium [6]. This suggestion predicts presence of the specific membrane contact sites between acidic organelles and the ER. So, relationship between acidic organelles of the endolysosomal system to $\mathrm{ER} \mathrm{Ca}^{2+}$ store remains unclear. The recycling of endosome and fusion of lysosome to autophagosome as results of autophagy may affect this relationship. Thus, different ions transported systems may be also involved in this process.

The main goal of this study was to examine influence of bafilomycine $A 1$ and NAADP on activity of ATPases for better understanding relationship between the acidic organelles and endoplasmic reticulum / plasmatic membrane. At the same time, these results should provide a comprehension of bafilomycine A1 safety as an anticancer drug.

ISSN 1996-4536 (print) • ISSN 2311-0783 (on-line) • Біологічні Студії / Studia Biologica • 2015 • Том 9/№3-4 • С. 31-40 


\section{MATERIALS AND METHODS}

Isolation of a subcellular fraction. Experiments were conducted on male and female nonlinear white type rats $(0.18-0.2 \mathrm{~kg})$. All procedures with animals were in accordance with the "International Convention for working with animals" under approval of the Bioethics Committee of Biologycal Faculty (Ivan Franko National University of Lviv) (Protocol N 11/15 dated by 10.12.2015). After ether anaesthesia rats were decapitated. Isolated rat liver was perfused briefly with homogenizing medium (buffer solution) containing $(\mathrm{mmol} / \mathrm{L})$ : sucrose - 250.0; EDTA - 1.0; Tris- $\mathrm{HCl}-10.0\left(\mathrm{pH} 7.4 \mathrm{t}=37^{\circ} \mathrm{C}\right)$. Then, chilled tissue was crushed by passing through the press. Next, buffer solution was added to the minced liver Minced tissue was added buffer solution (in a ratio of 1:8) and tissue was homogenized with a Potter-Elvehjam teflon-glass homogenizer at a speed of $300 \mathrm{rev} / \mathrm{min}$. Liver subcellular fractions obtained by differential centrifugation, the essence of which is to conduct a series of successive centrifuging the mixture of organelles and membrane fragments obtained after homohenization of tissue. First of all, homogenates were centrifuged for $10 \mathrm{~min}$ at $3000 \mathrm{~g}$ (centrifuge PC-6) for the deposition of intact cells and nuclei, mitochondrial fraction precipitated for 10 minutes on a $6500 \mathrm{~g}$ and a temperature $0-2{ }^{\circ} \mathrm{C}$. The resulting postmitochondrial supernatant used in the experiment as "subcellular fractions of rat liver".

Measurement of the ATPase activity. ATPase activity was determined by orthophosphate content released after ATP hydrolysis. At the beginning of the experiment $200 \mu \mathrm{L}$ of subcellular fraction were transferred to a standard incubation medium which contained (mmol/L) NaCl - 50.0; KCl - 100.0; Tris- $\mathrm{HCl}-20.0 ; \mathrm{MgCl}_{2}-3.0 ; \mathrm{CaCl}_{2}-$ $0.01 ; \mathrm{NaN}_{3}-1 ; \mathrm{ATP}-3.0 ; \mathrm{pH} 7.4$ at $37^{\circ} \mathrm{C}$. The reaction was started by adding $3 \mathrm{mM}$ ATP (Sigma) and incubating samples for $15 \mathrm{~min}$ at $37^{\circ} \mathrm{C}$ at moderate shaking in a water bath. Before the end of incubation $0.4 \mathrm{ml}$ of medium was taken for the determination of protein content by the method of Lowry [15]. For activation NAADP-induced $\mathrm{Ca}^{2+}$-releasing we used NAADP (Sigma) at subthreshold concentration $7 \mu \mathrm{mol} / \mathrm{L}$. Bafilomycine A1 (Sigma) was used as inhibitor V-ATPase at high concentration $1 \mu \mathrm{mol} / \mathrm{L}$. To compare the impact NAADP against the background of bafilomycine A1 we conducted two parallel incubation samples that contained bafilomycine $A 1$ alone and simultaneous presence bafilomycine A1 and NAADP. Reaction was stopped by adding $5 \mathrm{ml}$ of $10 \%$ trichloroacetic acid to samples and incubating them for 10 min followed by $10 \mathrm{~min}$ centrifugation at $1600 \mathrm{~g}$. Supernatant obtained was used to determine the content of inorganic phosphorus by the spectrophotometric method of Fiske-Subbarow.

The total ATPase activity of subcellular fraction was calculated as a difference of inorganic phosphorus in the media with different composition (with bafilomycine A1 or NAADP) expressed as micromoles of inorganic phosphorus equivalent to $1 \mathrm{mg}$ of protein per $1 \mathrm{~h}$. Specific $\mathrm{Na}^{+} / \mathrm{K}^{+}$-ATPase activity was calculated as difference of inorganic phosphorus content in medium with or without ouabain (Sigma) at concentration $1 \mathrm{mmol} / \mathrm{L}$. For the determination of $\mathrm{Ca}^{2+} / \mathrm{Mg}^{2+}$-ATPase activity, we quantified the difference between the total $\mathrm{Ca}^{2+} / \mathrm{Mg}^{2+}$ - and $\mathrm{Na}^{+} / \mathrm{K}^{+}$-ATPase activity. Thapsigargin $(1 \mathrm{mkmol} / \mathrm{L})$ was used to calculate SERCA contribution into the total $\mathrm{Ca}^{2+} / \mathrm{Mg}^{2+}$-ATPase activity. Specific basal $\mathrm{Mg}^{2+}$-ATPase activity was determined in incubation medium that contained $1 \mathrm{mmol} / \mathrm{L}$ EGTA (Sigma) and lacked ouabain. In all experiments, as a control for the absence of enzymatic ATP hydrolysis was incubation medium with no added tissue.

Data analysis. A significance of differences between different groups was calculated using Wilcoxon-Mann-Whitney test or Student's t-test. $\mathrm{P}<0.05$ was considered to be statistically significant.

ISSN 1996-4536 (print) • ISSN 2311-0783 (on-line) • Біологічні Студії / Studia Biologica • 2015 • Том 9/№3-4 • С. 31-40 


\section{RESULTS AND DISCUSSION}

Activity of $\mathrm{Ca}^{2+}$-ATPases of rat liver postmitochondrial fraction under bafilomycine $A 1$ and NAADP action. Previously we established that NAADP substantial increase common $\mathrm{Ca}^{2+}$-ATPase activity in liver [24]. But it is still unknown which $\mathrm{Ca}^{2+}$ pumps realize this effect. Using thapsigargine as selective inhibitor of specific $\mathrm{Ca}^{2+}$ ATPase of ER (SERCA), we found that NAADP increased its activity on (142.87 \pm 18.05$) \%$ $(P \leq 0.05 ; n=5)$. It was also revealed that specific SERCA activity increased by 3 fold $(P \leq 0.05 ; n=5)$ under bafilomycine $A 1$ presence (Fig. 1$)$. At the same time no NAADP, nor bafilomycine A1 didn't cause statistically authentic change of specific activity of plasmatic membranes $\mathrm{Ca}^{2+}$-ATPase (PMCA) (Fig. 2). Besides it was also found that bafilomycine A1 completely prevented NAADP-induced increasing of specific SERCA activity (Fig. 1).
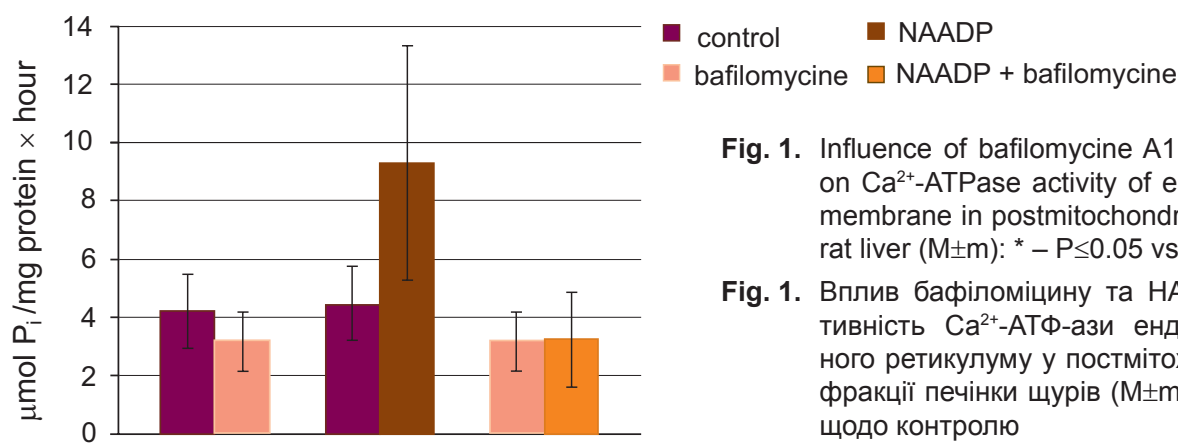

Fig. 1. Influence of bafilomycine A1 and NAADP on $\mathrm{Ca}^{2+}$-ATPase activity of endoplasmatic membrane in postmitochondrial fraction of rat liver $(\mathrm{M} \pm \mathrm{m})$ : * $-\mathrm{P} \leq 0.05$ vs control

Fig. 1. Вплив бафіломіцину та НААДФ на активність $\mathrm{Ca}^{2+}$-АТФ-ази ендоплазматичного ретикулуму у постмітохондріальній фрракції печінки щурів (M $\pm \mathrm{m})$ : * $-\mathrm{P} \leq 0,05$ щодо контролю

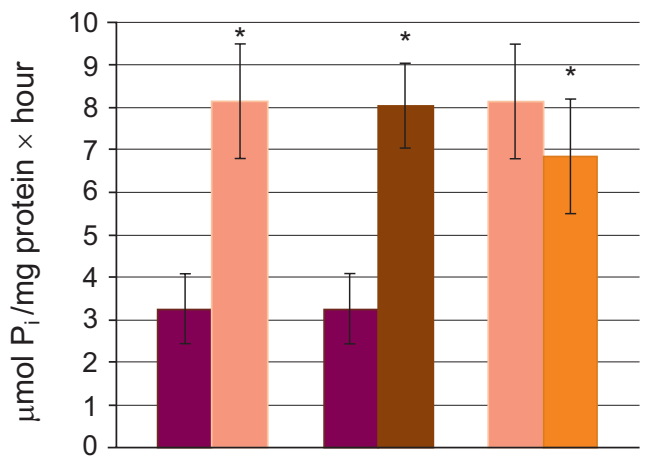

control NAADP
bafilomycine NAADP + bafilomycine

Fig. 2. Influence of bafilomycine $A 1$ and NAADP on plasmatic membrane $\mathrm{Ca}^{2+}$-ATPase activity in postmitochondrial fraction of rat liver $(\mathrm{M} \pm \mathrm{m})$

Рис. 2. Вплив бафріломіцину А1 і НААДФ на активність Са ${ }^{2+}$-АТФ-ази плазматичної мембрани у постмітохондріальній фракції печінки щурів

Thus separately bafilomycine A1 and NAADP cause the same effect on SERCA due to local increasing of $\mathrm{Ca}^{2+}$ concentration. It is possible only if there is close position between an acidic store and ER. Our data also confirmed that NAADP-sensitive $\mathrm{Ca}^{2+}$-store in hepatocytes is at the same time bafilomycine A1-sensitive. That is why bafilomycine A1 completely prevented NAADP's effect on SERCA. Our finding is made agree with Kilpatrick and other (2013) postulated existing lysosome-ER membrane contact sites [13]. It is important to note that there was no effect of NAADP and bafilomycine A1 on PMCA. This means that acidic store is not associated to PM in this subcellular fraction.

Activity of $\mathrm{Na}^{+} / \mathrm{K}^{+}$-ATPases of rat liver subcellular fraction under bafilomycine $A 1$ and NAADP action. Besides $\mathrm{Na}^{+} / \mathrm{K}^{+}$-ATPase is responsible for generating and maintaining transmembrane ionic gradients that are of vital importance for cellular 
function and subservient activities such as volume regulation, $\mathrm{pH}$ maintenance, and generation of action potentials and secondary active transport as well as calcium content through $\mathrm{Na}^{+} / \mathrm{H}^{+}$- and $\mathrm{Na}^{+} / \mathrm{Ca}^{2+}$-exchangers, respectively [11]. It was shown that $\mathrm{Na}^{+} /$ $\mathrm{K}^{+}$-ATPases is a key player in the regulation of endosomal $\mathrm{pH}$ and endocytosed membrane traffic [11]. Presumably, functional $\mathrm{Na}^{+} / \mathrm{K}^{+}$-ATPases are retained within the plasma membrane/endosomal axis as a result of endosome recycling [19]. They reinforce a lumen positive membrane potential and therefore will inhibit $\mathrm{H}^{+}$pumping in the membrane of organelles [19]. So $\mathrm{Na}^{+} / \mathrm{K}^{+}$-ATPase inhibits acidification of endosomes lumen [11]. We found that bafilomycine $A 1$ decreased activity of $\mathrm{Na}^{+} / \mathrm{K}^{+}$-ATPase by $(41.67 \pm 7.03) \%(P \leq 0.001 ; n=6)$ (Fig. 3). It is probably due to inhibition of $\mathrm{H}^{+}$-pump by bafilomycine $\mathrm{A} 1$ and alkalization of endosome's lumen. The dependence of $\mathrm{Na}^{+} / \mathrm{K}^{+}-$ ATPase activity on $\mathrm{pH}$ in the range of $6.0-7.5$ is characterized by the bell-shaped curve [14]. Alkalization more than $\mathrm{pH} 7.5$ inhibits this protein as well as acidification lower $\mathrm{pH} 6.0$ [14]. Previously it was also found that NAADP decreased specific activity of $\mathrm{Na}^{+} / \mathrm{K}^{+}$-ATPase [24]. A.J. Morgan et al. estimated that NAADP caused alkalization of endo-lysosomal lumen [18]. Thus, most likely that NAADP, as well as bafilomycine A1, decreased activity of $\mathrm{Na}^{+} / \mathrm{K}^{+}$-ATPase due to a increse in $\mathrm{pH}$.

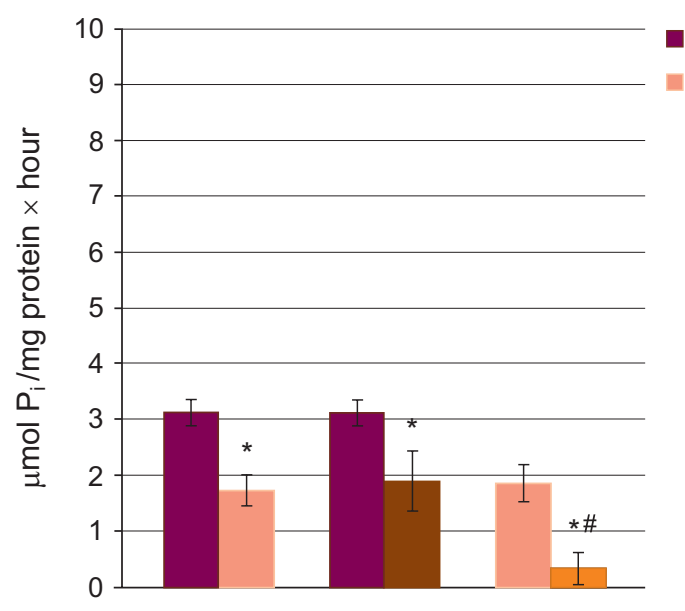

Fig. 3. Influence of bafilomycine $A 1$ and NAADP on $\mathrm{Na}^{+} / \mathrm{K}^{+}$-ATPase activity in postmitochondrial fraction of rat liver $(\mathrm{M} \pm \mathrm{m})$ : * $\mathrm{P} \leq 0.05$ vs control; \# $-\mathrm{P} \leq 0.05$ vs bafilomycine

Fig. 3. Вплив бафріломіцину та НААДФ на активність $\mathrm{Na}^{+}, \mathrm{K}^{+}$-АТФ-ази у постмітохон-

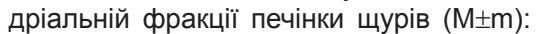
* - Р $\leq 0,05$ щодо контролю; \# - P $\leq 0,05$ щодо бафіломіцину

The TPCs family of endolysosomal proteins was shown to be regulated by NAADP [3]. Based on their sequence similarity to voltage-gated $\mathrm{Ca}^{2+} / \mathrm{Na}^{+}$channels, TPCs are predicted to comprise two homologous domains each consisting of 6 transmembrane regions with a putative pore-forming domain located between the $5^{\text {th }}$ and $6^{\text {th }}$ membranespanning regions [20]. Recently, it was shown that endolysosomal ATP-sensitive $\mathrm{Na}^{+}$channel (lysoNa(ATP)) is a complex formed by TPC1 and TPC2 [8]. It was also demonstrated that TPC2/NAADP/Ca ${ }^{2+}$ signaling alkalinizes lysosomal $\mathrm{pH}$ to specifically inhibit the later stage of basal autophagy progression [16]. Such as TPCs function as $\mathrm{Na}^{+}$-selective channels apparently insensitive to NAADP, so it is possible to assume that under NAADP action $\mathrm{Na}^{+}$concentration inside the luman of endosomal store may changed and this also decreased activity of $\mathrm{Na}^{+} / \mathrm{K}^{+}-\mathrm{ATPase}$.

After preincubation of liver subcellular fraction with bafilomycine A1, next applying NAADP caused more intensive decreasing of $\mathrm{Na}^{+} / \mathrm{K}^{+}$-ATPase activity. Such as bafilomycine A1 amplified NAADP's effect we assumed that it is possible an existing of

ISSN 1996-4536 (print) • ISSN 2311-0783 (on-line) • Біологічні Студії / Studia Biologica • 2015 • Том 9/№3-4 • С. 31-40 
NAADP-sensitive but bafilomycine-insensitive store in this subcellular fraction. This assumption was made early observing decreasing of stored calcium in permeabilized hepatocytes, which was not sensitive to thapsigargine or nigericine [6]. This store is the most likely represented by endosome, which may possess $\mathrm{Na}^{+} / \mathrm{K}^{+}$-pump as results of endocytosis [11].

Summarizing these data, we assume that $\mathrm{Na}^{+} / \mathrm{K}^{+}$-ATPase may be active in the endosomal organels and bafilomycine A1, as well as NAADP decreased pump's activity due to alkalization of endosomal luman.

Influence of bafilomycine $\mathrm{A1}$ and NAADP on basal $\mathrm{Mg}^{2+}$-ATPase activity in rat liver subcellular fraction. It should to note that activity of basal $\mathrm{Mg}^{2+}$-ATPase is coupled to $\mathrm{H}^{+}$-translocation in plasma membrane $[17 ; 23]$ as well as in endosomal fraction [21]. Also in hepatocytes $\mathrm{Mg}^{2+}$-ATPase is considered as markers of canalicular memebrane [1]. It was observed that bafilomycine $\mathrm{A} 1$ caused increasing of basal $\mathrm{Mg}^{2+}$-ATPase activity by $(60.13 \pm 11.68) \%(P \leq 0.05 ; n=15)$ (Fig. 4). This effect doesn't associated with the calcium concentration increasing because of EGTA presence in incubation medium. The most likely that bafilomycine's effect is due to $\mathrm{pH}$ changing. Previously NAADP-induced decreasing of basal $\mathrm{Mg}^{2+}$-ATPase activity was found in subcellular fraction of rat liver, which has been also explained by NAADP-induced alkalization of endo-lysosomal luman [24]. Our results are in agreement with kinetic interpretation of the original $\mathrm{pH}$-dependence of enzymatic activity of basal $\mathrm{Mg}^{2+}$-ATPase of the smooth muscle sarcolemma [14]. S. O. Kosterin et al. [14] showed that a cause of linear $\mathrm{pH}$-dependence of enzymatic activity of the basal $\mathrm{Mg}^{2+}$-ATPase is that $\mathrm{H}^{+}$is a competitive inhibitor of given enzyme: the increase of protons concentration leads to a decrease of the affinity of $\mathrm{Mg}^{2+}$-ATP substrate for the enzyme. Our data suggest that bafilomycine A1, as well as NAADP, decrease basal $\mathrm{Mg}^{2+}$-ATPase activity due to alkalization of endo-lysosomal lumen.

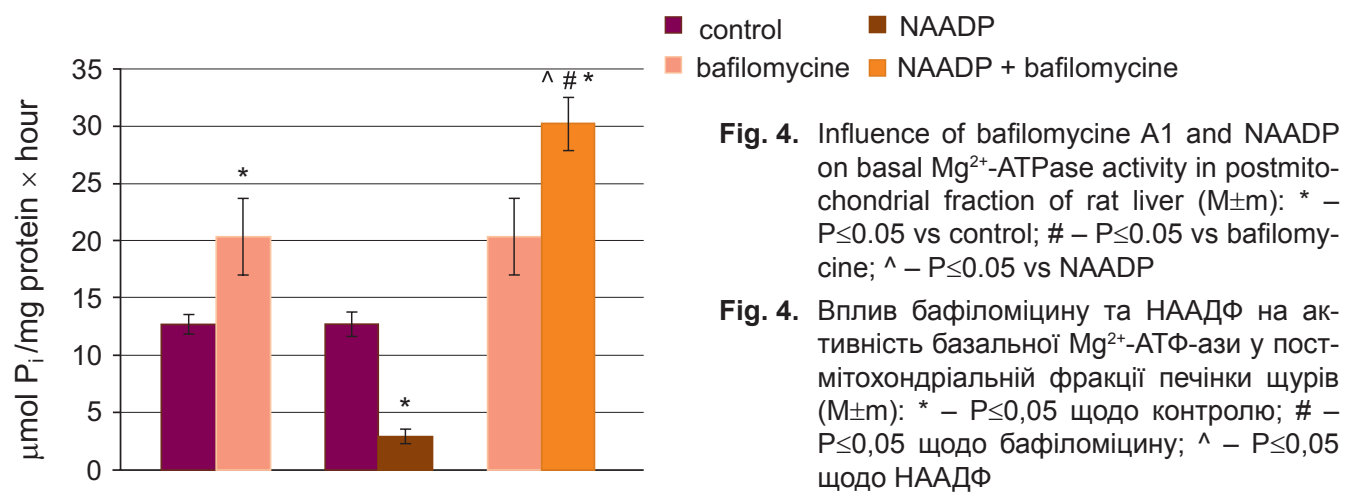

Simultaneous presence at incubation medium of bafilomycine A1 and NAADP caused an increase of basal $\mathrm{Mg}^{2+}$-ATPase activity by 2 folds $(P \leq 0.05 ; n=15)$ compared to control (Fig. 4). So, NAADP intensify the effect of bafilomycine A1 which confirm presence of the additional NAADP-sensitive store in this subcellular fraction.

This supports our hypothesis that NAADP and bafilomycine A1 cause changes of $\mathrm{pH}$ inside the endo-lysosomal ogranels, as well as in the incubation medium.

ISSN 1996-4536 (print) • ISSN 2311-0783 (on-line) • Біологічні Студії / Studia Biologica • 2015 • Том 9/№3-4 • С. 31-40 


\section{CONCLUSIONS}

It was shown that SERCA activity increased under bafilomycine A1 presence as well as NAADP in rat liver postmitochondrial fraction. At the same time, changes in PM $\mathrm{Ca}^{2+}$-ATPase activity were not found. These effects are explained by an existing of lysosome-ER membrane contact sites with close apposition between NAADP-sensitive $\mathrm{Ca}^{2+}$ channels of acidic store and SERCA. Previously, preincubation of rat liver postmitochondrial fraction with bafilomycine A1 completely prevented to NAADP-induced increasing of SERCA activity. It was made conclusion that NAADP-sensitive store is at the same time bafilomycine A1-sensitive, which has direct contact sites to ER, but not to PM.

It was found that bafilomycine $\mathrm{A} 1$ decreased activity of $\mathrm{Na}^{+} / \mathrm{K}^{+}$-ATPase and amplificated NAADP-induced decreasing of $\mathrm{Na}^{+} / \mathrm{K}^{+}$-ATPase activity. After preincubation of liver subcellular fraction with bafilomycine A1 next applying NAADP caused more intensive decreasing of $\mathrm{Na}^{+} / \mathrm{K}^{+}$-ATPase activity, and bafilomycine A1 amplified NAADP's effect. We assumed that $\mathrm{Na}^{+} / \mathrm{K}^{+}$-ATPase may be active in endosomal organels and bafilomycine A1, as well as NAADP decreased its activity due to alkalization of their luman. Besides, existing of NAADP-sensitive but bafilomycine-insensitive store in this subcellular fraction is supposed, which is more likely represented by the endosomes. It was also observed that bafilomycine A1 caused an increase in basal $\mathrm{Mg}^{2+}$-ATPase activity, and NAADP intensify bafilomycine A1 -induced changes of this pump function. These effects are realized due to changes of $\mathrm{pH}$ inside the endo-lysosomal organelles.

Thus, close association between bafilomycine-sensitive store and ER is postulated for rat liver postmitochondrial fraction. Bafilomycine A1 applying changes activity of active ion-transport systems which may disturb as trasformation of the endolysosomal systems organelles due to $\mathrm{pH}$ changes.

1. Bennett L. Blitzer, Barbara R. et al. Hepatic adenosine triphosphate-dependent $\mathrm{Ca}^{2+}$ transport is mediated by distinct carriers on rat basolateral and canalicular membranes. J. Clin. Invest, 1989; 83: 1319-1325.

2. Bowman E.J., Graham L.A., Stevens T.H. et al. The bafilomycin/concanamycin binding site in subunit $\mathrm{c}$ of the VATPases from Neurospora crassa and Saccharomyces cerevisiae. J. Biol. Chem, 2004; 279(32): 33131-33138.

3. Brailoiu E., Churamani D., Cai $X$. et al. Essential requirement for two-pore channel 1 in NAADP-mediated calcium signaling. J. Cell Biol, 2009; 186: 201-209.

4. Bychkova S. $\mathrm{Ca}^{2+}$ releasing process and nicotinic acid adenine dinucleotide phosphate. Studia Biologica, 2013; 7(2): 195-206.

5. Bychkova S.V. NAADP-sensitive $\mathrm{Ca}^{2+}$ stores in permeabilized rat hepatocytes. Ukr. Biochem. J, 2014; 86(5): 65-73.

6. Bychkova S.V., Chorna T.I. NAADP-sensitive $\mathrm{Ca}^{2+}$ stores in permeabilized rat hepatocytes. Ukr. Biochem. J, 2014; 86(5): 65-73.

7. Chorna T., Bychkova S. Influence of ryanodine on ATPase activity of rat hepatocytes membrane after perfusion of liver by insulin-content solution. Visnyk of the Lviv University. Series Biology, 2011; 55: 170-178 (In Ukrainian).

8. Chunlei C., Zhou Y., Navarro B. et al. mTOR Regulates Lysosomal ATP-Sensitive Two-Pore $\mathrm{Na}^{+}$Channels to Adapt to Metabolic State. Cell, 2013; 152(4): 778-790.

9. Churchill, G.C., Okada, Y., Thomas, J.M. et al. NAADP mobilizes $\mathrm{Ca}^{2+}$ from reserve granules, a lysosome-related organelle, in sea urchin eggs. Cell, 2002; 111: 703-708.

10. Dammermann W., Guse A.H. Functional ryanodine receptor expression is required for NAADP-mediated local $\mathrm{Ca}^{2+}$ signaling in T-lymphocytes. J. Biol. Chem., 2005; 280: 2139421399.

ISSN 1996-4536 (print) • ISSN 2311-0783 (on-line) • Біологічні Студії / Studia Biologica • 2015 • Том 9/№3-4 • С. 31-40 
11. Feldmann T., Glukmann V., Medvenev E. et al. Role of endosomal $\mathrm{Na}^{+}-\mathrm{K}^{+}-\mathrm{ATP}$ ase and cardiac steroids in the regulation of endocytosis. Am. J. Physiol. Cell Physiol, 2007; 293(3): 885-896.

12. Gerasimenko J.V., Sherwood M., Tepikin A.V. et al. NAADP, cADPR and IP 3 all release $\mathrm{Ca}^{2+}$ from the endoplasmic reticulum and an acidic store in the secretory granule area. J. Cell Sci, 2006; 119: 226-238.

13. Kilpatrick B.S., Eden E.R., Schapira A.H. et al. Direct mobilisation of lysosomal $\mathrm{Ca}^{2+}$ triggers complex $\mathrm{Ca}^{2+}$ signals. J. Cell Sci, 2013; 126(1): 60-66.

14. Kosterin S.O., Veklich T.O., Pryluts'kyi lu.l. et al. Kinetic interpretation of the original pH-dependence of enzymatic activity of "basal” $\mathrm{Mg}^{2+}$-ATPase of the smooth muscle sarcolemma. Ukr. Biokhim. Zh, 2005; 77(6):37-45 (In Ukrainian).

15. Lowry O.H., Rosebrough N.J., Farr A.L. et al. Protein measurement with the folin phenol reagent, J. Biol. Chem, 1951; 193: 265-275.

16. Lu Y., Hao B.X., Graeff R. et al. Two pore channel 2 (TPC2) inhibits autophagosomal-lysosomal fusion by alkalinizing lysosomal pH. J. Biol. Chem, 2013; 288(33): 24247-63.

17. Luu-The V., Goffeau A., Thinès-Sempoux D. Rat liver plasma membrane $\mathrm{Ca}^{2+}$ - or $\mathrm{Mg}^{2+}$-activated ATPase. Evidence for proton movement in reconstituted vesicles. Biochim. Biophys. Acta, 1987; 904(2): 251-8.

18. Morgan A.J., Davis L.C., Wagner S.K. et al. Bidirectional Ca2+ signaling occurs between endoplasmic reticulum and acidic organelles. J. Cell Biol, 2013; 200(6): 789-805.

19. Morgan A.J., Platt F.M., Lloyd-Evans E. et al. Molecular mechanisms of endolysosomal $\mathrm{Ca}^{2+}$ signalling in health and disease. Biochem. J, 2011; 439: 349-374.

20. Patel S., Ramakrishnan L., Rahman T. et al. The endo-lysosomal system as an NAADP-sensitive acidic $\mathrm{Ca}^{2+}$ store: role for the two-pore channels. Cell Calcium, 2011. 50(2): 157-167.

21. Saermark T., Flint N., Evans W.H. Hepatic endosome fractions contain an ATP-driven proton pump. Biochem. J., 1985; 225: 51-58.

22. Saftig P., Klumperman J. Lysosome biogenesis and lysosomal membrane proteins: trafficking meets function. Nat. Rev. Mol. Cell Biol, 2009; 10: 623-635.

23. Veklich T.O., Kosterin S.O. Comparative study of properties of $\mathrm{Na}^{+}, \mathrm{K}^{+}$-ATPase and $\mathrm{Mg}^{2+}$ ATPase of the myometrium plasma membrane. Ukr. Biokhim. Zh, 2005; 77(2): 66-75. (In Ukrainian).

24. Vergun M., Bychkova S. ATPase activity of rat hepatocytes membrane under the influence of nicotinic acid adenine dinucleotide phosphate. Visnyk of the Lviv University. Series Biology, 2014; 65: 335-341.

25. Wang X., Zhang X., Dong X.P. et al. TPC proteins are phosphoinositide- activated sodiumselective ion channels in endosomes and lysosomes. Cell, 2012; 151(2): 372-83.

26. Yamamoto A., Tagawa Y., Yoshimori T. et al. Bafilomycin A1 prevents maturation of autophagic vacuoles by inhibiting fusion between autophagosomes and lysosomes in rat hepatoma cell line, H-4-II-E cells. Cell Struct. Funct, 1998; 23(1): 33-42.

\section{ПЛИВ БАФІЛОМІЦИНУ ТА НААДФ НА АКТИВНІСТЬ АТФ-аз ПОСТМІТОХОНДРІАЛЬНОЇ ФРАКЦІЇ ПЕЧІНКИ ЩУРІВ}

\section{С. В. Бичкова}

Львівський національний університет імені Івана Франка вул. Грушевського, 4, Львів 79005, Україна e-mail: s.bychkova@gmail.com

У клітині відбувається постійне рециклювання органоїдів ендо-лізосомальної системи, які належать до так званого “кислотного депо" клітини. $\mathrm{H}^{+}$-АТФ-аза створює трансмембранний протонний градієнт на цих мембранах, закислюючи їхній вміст. Селективний інгібітор $\mathrm{H}^{+}$-помпи бафріломіцин використовують як протипухлинний препарат, проте мало вивченою є його безпечність для нормальних клітин. 
Кислотні депо є одночасно $\mathrm{Ca}^{2+}$-вмісними органоїдами, які можуть вивільнювати кальцій за дії нікотинацидаденіндинуклеотидфосфрату (НААДФ). Для клітин печінки з'ясовано, що кислотні депо $є$ НААДФ-чутливими. Проте невивченим є взаємозв'язок між системами активного транспорту йонів та кислим депо гепатоцитів, який може відображати стан рециклювання органоїдів ендо-лізосомальної системи у клітині. Метою роботи було дослідити вплив бафріломіцину та НААДФ на активність $\mathrm{Na}^{+}, \mathrm{K}^{+}$АТФ-ази, базальної $\mathrm{Mg}^{2+}$-АТФ-ази і Са ${ }^{2+}$-АТФ-ази плазматичної мембрани (ПМ) та ендоплазматичного ретикулуму (ЕПР) для розуміння можливих взаємозв'язків між органоїдами ендо-лізосомального депо і ЕПР/ПМ та оцінити можливість використання бафріломіцину як протипухлинного препарату. Досліди проведені на без'ядерній і безмітохондріальній фракції печінки щурів, яку отримували методом диференційного центрифугування. Визначали активність АТФ-аз, вимірюючи вміст неорганічного фросфору методом Фіске-Субарроу.

3'ясовано, що бафріломіцин викликає зростання активності $\mathrm{Ca}^{2+}$-помпи ЕПР і не впливає на $\mathrm{Ca}^{2+}$-помпу ПМ. За дії НААДФ також зростає активність $\mathrm{Ca}^{2+}$-помпи ЕПР і нема змін у роботі $\mathrm{Ca}^{2+}$-помпи ПМ. Після попередньої преінкубації субклітинної фрракції печінки щурів із бафріломіцином ми не виявили впливу НААДФ ні на $\mathrm{Ca}^{2+}$ помпу ЕПР, ані на $\mathrm{Ca}^{2+}$ помпу ПМ. Виявлено, що за дії бафріломіцину знижується активність $\mathrm{Na}^{+}, \mathrm{K}^{+}$-АТФ-ази. Преінкубація з бафріломіцином ще більше підсилювала викликане НААДФ пригнічення активності цієї помпи. Встановлено, що за дії бафріломіцину зростає активність базальної $\mathrm{Mg}^{2+}$-АТФ-ази. Преінкубація субклітинної фрракції печінки з НААДФ підсилює підвищення базальної $\mathrm{Mg}^{2+}$-АТФ-азної активності за дії бафріломіцину. Ці ефекти, на нашу думку, пов'язані із бафріломіциніндукованию зміною $\mathrm{pH}$, а також реалізуються через локальні сайти з підвищеною концентрацією кальцію.

Зроблено висновок про активне рециклювання органоїдів ендо-лізосомального кислого депо у клітинах печінки. Ми вважаємо, що НААДФ-чутливе депо гепатоцитів є бафріломіцин-чутливим та має функціональний і фрізичний контакт з мембранами ЕПР. Разом з тим, ми припускаємо існування певної частки ендо-лізосомального депо, яка не є чутлива до бафіломіцину, але чутлива до НААДФ і, очевидно, представлена ендосомами. Отже, застосування бафріломіцину як протипухлинного препарату може впливати на здорові клітини печінки, що виявлятиметься у порушенні внутрішньоклітинного рециклювання.

Ключові слова: кисле депо, бафріломіцин, Н+-помпа, ендо-лізосомальна система клітин, АТФ-азна активність, НААДФ, $\mathrm{Na}^{+}, \mathrm{K}^{+}$-помпа,

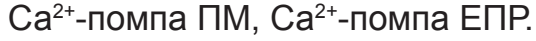

\section{ВЛИЯНИЕ БАФИЛОМИЦИНА И НААДФ НА АКТИВНОСТЬ АТФ-а3 ПОСТМИТОХОНДРИАЛЬНОЙ ФРАКЦИИ ПЕЧЕНИ КРЫС}

\section{C. В. Бычкова}

Львовский национальный университет имени Ивана Франко ул. Грушевского, 4, Львов 79005, Украина e-mail: s.bychkova@gmail.com

В клетке происходит постоянное рециклирование органоидов эндо-лизосомальной системы, принадлежащих к так называемому “кислотному депо” клетки.

ISSN 1996-4536 (print) • ISSN 2311-0783 (on-line) • Біологічні Студії / Studia Biologica • 2015 • Том 9/№3-4 • C. 31-40 
Н+-АТФ-аза создает трансмембранный протонный градиент на этих мембранах, закисляя их изнутри. Селективный ингибитор $\mathrm{H}^{+}$-помпы бафиломицин используют как противоопухолевый препарат, однако мало изученной является его безопасность для нормальных клеток. Кислотные депо являются одновременно $\mathrm{Ca}^{2+}$-содержащими органоидами, которые могут освобождать кальций при действии никотинацидадениндинуклеотидфосфрата (НААДФ). Для клеток печени показано, что кислотные депо являются НААДФ-чувствительными. Однако не изучена взаимосвязь между системами активного транспорта ионов и кислым депо гепатоцитов, которая может отображать состояние рециклирования органоидов эндо-лизосомальной системы в клетке. Целью работы было исследовать влияние бафиломицина и НААДФ на активность $\mathrm{Na}^{+}, \mathrm{K}^{+}$-АТФ-азы, базальной $\mathrm{Mg}^{2+}$-АТФ-азы и $\mathrm{Ca}^{2+}$ АТФ-азы плазматической мембраны (ПМ) и эндоплазматического ретикулума (ЭПР) для понимания возможных взаимосвязей между органоидами эндо-лизосомального депо и ЭПР/ПМ и оценить возможность использования бафиломицина как противоопухолевого препарата. Опыты проведены на безъядерной и безмитохондриальной фракции печени крыс, которую получали методом дифференциального центрифугирования. Определяли активность АТФ-аз, измеряя содержание неорганического фосфора методом Фиске-Субарроу.

Показано, что бафиломицин вызывает рост активности $\mathrm{Ca}^{2+}$-помпы ЭПР и не влияет на $\mathrm{Ca}^{2+}$-помпу ПМ. При действии НААДФ также возрастает активность $\mathrm{Ca}^{2+}$-помпы ЭПР и нет изменений в работе $\mathrm{Ca}^{2+}$-помпы ПМ. После предварительной преинкубации субклеточной фракции печени крыс с бафиломицином мы не обнаружили влияния НААДФ ни на $\mathrm{Ca}^{2+}$-помпу ЭПР, ни на $\mathrm{Ca}^{2+}$-помпу ПМ. Выявлено, что при действии бафиломицина снижается активность $\mathrm{Na}^{+}, \mathrm{K}^{+}$-АТФ-азы. Преинкубация с бафиломицином еще больше усиливала вызваное НААДФ подавление активности этой помпы. Установлено, что при действии бафиломицина возрастает активность базальной $\mathrm{Mg}^{2+}$-АТФ-азы. Преинкубация субклеточной фракции печени с НААДФ усиливает повышение базальной $\mathrm{Mg}^{2+}$-АТФ-азной активности при воздействии бафиломицина. Эти эфффекты, по нашему мнению, связаны с бафиломицин-индуцированным изменением $\mathrm{pH}$, а также реализуются через локальные сайты с повышенной концентрацией кальция.

Сделан вывод об активной рециклизации органоидов эндо-лизосомального кислого депо в клетках печени. Мы считаем, что НААДФ-чувствительное депо гепатоцитов является бафиломицин-чувствительным и имеет функциональный и фризический контакт с мембранами ЭПР. А также мы предполагаем существование определенной доли эндо-лизосомального депо, которое не чувствительно к бафиломицину, но чувствительно к НААДФ и, очевидно, представлено эндосомамы. Таким образом, применение бафиломицина как противоопухолевого препарата может влиять на здоровые клетки печени, проявляясь в нарушении внутриклеточной рециклизации.

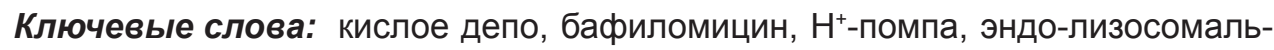
ная система клеток, АТФ-азная активность, НААДФ, $\mathrm{Na}^{+}$, $\mathrm{K}^{+}$-помпа, $\mathrm{Ca}^{2+}$-помпа ПМ, $\mathrm{Ca}^{2+}$-помпа ЭПР.

Одержано: 18.10.2015

ISSN 1996-4536 (print) • ISSN 2311-0783 (on-line) • Біологічні Студії / Studia Biologica • 2015 • Том 9/№3-4 • С. 31-40 